\title{
Fluorescence Polarization Combined Capillary Electrophoresis Immunoassay for the Sensitive Detection of Genomic DNA Methylation
}

\author{
Xiaoli Wang, Yuling Song, Maoyong Song, Zhixin Wang, Tao Li, and Hailin Wang* \\ State Key Laboratory of Environmental Chemistry and Ecotoxicology, Research Center for Eco-Environmental \\ Sciences, Chinese Academy of Sciences, Beijing, China, 100085
}

Genomic DNA hypomethylation is epigenetically associated with aberrant gene expression and chromosome instability. Here we describe a method for rapid and sensitive detection of genomic DNA methylation without the need for bisulfite conversion, enzymatic digestion, or PCR amplification. The methylated DNA is first specifically recognized by an anti-5-methylcytosine $\operatorname{IgG}_{1}$ antibody and noncovalently labeled by a monovalent,

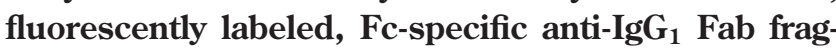
ment (secondary antibody). The formed immunocomplex of methylated DNA can be efficiently focused and separated from the DNA unbound secondary antibody by capillary electrophoresis (CE). The free fluorescent dye comigrates with the immuno-complex. However, by taking advantage of online laser-induced fluorescence polarization detection (LIFP), the target immuno-complex can be distinguished and accurately measured from the overlapped dye without further separation. The developed method is highly sensitive with a LOD of $0.3 \mathrm{nM}$ and is highly specific for the detection of methylated DNA. Moreover, the CE-LIFP immunoassay is rapid (1.2 min for one analysis) and only consumes less than $0.1 \mathrm{ng}$ of genomic DNA. The method was validated by examining human cell lines treated by methyltransferase inhibitor 5-aza-2'-deoxycytidine at low doses $(10 \mathrm{nM}-10 \mu \mathrm{M})$. Because of its sensitivity and speed, our method will be applicable for rapid epigenetic evaluation and for the study of tumorigenesis and chemical-cell interactions.

Methylation of the position 5 of cytosine in DNA by methyltransferases is a primary epigenetic mechanism and plays crucial roles in gene transcription, embryogenesis, and diseases. ${ }^{1} \mathrm{Im}$ portantly, DNA methylation can be inherited through "maintenance methylation" of hemimethylated sites in newly synthesized DNA, ${ }^{2}$ surviving multiple rounds of mitotic cell division and meiosis, ${ }^{3}$ or even nuclear transfer., ${ }^{4,5}$ The epigenetic changes during gestation may endure in at least four subsequent genera-

* To whom correspondence should be addressed. Phone/fax: 0086-1062849600. E-mail: hlwang@rcees.ac.cn.

(1) Weinhold, B. Environ. Health Perspect. 2006, 114, A160-167.

(2) Das, P. M.; Singal, R. J. Clin. Oncol. 2004, 22, 4632-4642.

(3) Cavalli, G.; Paro, R. Cell 1998, 93, 505-518.

(4) Ng, R. K.; Gurdon, J. B. Proc. Natl. Acad. Sci. U.S.A. 2005, 102, 19571962. tions of organisms. ${ }^{6}$ DNA methylation may repress transcription activity by interfering with the binding of regulatory factors to DNA or effecting the chromatin structure. ${ }^{7}$ Loss of normal DNA methylation, without accompanying alterations in DNA sequences, can change normal cellular functions and phenotypes, including genomic imprinting, ${ }^{8} \mathrm{X}$-chromosome inactivation in mammalian, ${ }^{9}$ retroviral silencing, ${ }^{10}$ activation and inactivation of specific genes, ${ }^{11}$ chromosome instability, ${ }^{12}$ and eye color of Drosophila. Aberrant DNA methylation is associated with environmental exposure, aging, and a wide range of diseases. ${ }^{2,13-15}$

Aberrant DNA methylation typically includes genomic DNA hypomethylation and gene-specific hypermethylation. The cytosine methylation levels of tumor-derived genomic DNA are significantly lower than that in normal cells. ${ }^{16}$ Many agents are known or suspected to change epigenetic processes, including heavy metals, pesticides, diesel exhaust, tobacco smoke, polycyclic aromatic hydrocarbons, hormones, radioactivity, viruses, bacteria, and basic nutrients. ${ }^{17}$ However, it remains unknown for a multitude of substances whether epigenetically toxic or nontoxic. Regarding the diversity of the substances and related dose variability, rapid and large-scale epigenetic evaluation is required. With the use of genomic DNA methylation analysis, it is possible to carry out rapid evaluation or large-scale screening. In particular, genomic DNA hypomethylation is generally associated with chromosomal instability, ${ }^{12}$ and genomic DNA methylation analysis is meaningful in a global picture. Recent study showed the correlation of genomic DNA hypomethylation with high serum-persistent organic pollutants in Greenlandic Inuit. ${ }^{15}$

(5) Wade, P. A.; Archer, T. K. Environ. Health Perspect. 2006, 114, A140141.

(6) Anway, M. D.; Cupp, A. S.; Uzumcu, M.; Skinner, M. K. Science 2005, 308, 1466-1469.

(7) Jaenisch, R.; Bird, A. Nat. Genet. 2003, 33, 245-254.

(8) Li, E.; Beard, C.; Jaenisch, R. Nature 1993, 366, 362-365.

(9) Heard, E.; Clerc, P.; Avner, P. Annu. Rev. Genet. 1997, 31, 571-610.

(10) Walsh, C. P.; Chaillet, J. R.; Bestor, T. H. Nat. Genet. 1998, 20, 116-117.

(11) Baylin, S. B.; Herman, J. G. Trends Genet. 2000, 16, 168-174.

(12) Chen, R. Z.; Pettersson, U.; Beard, C.; Jackson-Grusby, L.; Jaenisch, R. Nature 1998, 395, 89-93.

(13) Jones, P. A.; Baylin, S. B. Nat. Rev. Genet. 2002, 3, 415-428.

(14) Ehrlich, M. Oncogene 2002, 21, 5400-5413.

(15) Rusiecki, J. A.; Baccarelli, A.; Bollati, V.; Tarantini, L.; Moore, L. E.; BonefeldJorgensen, E. C. Environ. Health Perspect. 2008, 116, 1547-1552.

(16) Feinberg, A. P.; Gehrke, C. W.; Kuo, K. C.; Ehrlich, M. Cancer Res. 1988, 48, 1159-1161.

(17) Edwards, T. M.; Myers, J. P. Environ. Health Perspect. 2007, 115, 12641270.

Analytical Chemistry, Vol. 81, No. 19, October 1, 2009

7885 
A few methods have been developed for the detection of DNA methylation, targeting at genomic DNA, specific gene or locus, or genome or chromosome-wide $\mathrm{CpG}$ island methylation pattern. ${ }^{18}$ The methods for gene- or locus-specific analysis or methylation pattern analysis include methylation-specific PCR (MSP),${ }^{19} \mathrm{Me}-$ thylight, ${ }^{20}$ methylation-sensitive single nucleotide primer extension (Ms-SNuPE),${ }^{21}$ combined bisulfite restriction analysis (COBRA), ${ }^{22}$ and bisulfite PCR followed by capillary electrophoresis sequencing. Among these methods, the bisulfite PCR based sequencing method is promising because it can provide exquisite information about the position and molar fraction of 5-methylcytosine for each cytosine in the context of DNA sequence. ${ }^{23}$ However, there is a need for PCR correction in the presence of mixed methylated and unmethylated DNA. ${ }^{23}$ Although bisulfite PCR of repetitive DNA elements may be used as a surrogate for estimation of the genomic methylation, most of these methods lack the ability to detect DNA methylation levels at the genomic scale. Genomic DNA methylation can be analyzed by the cytosine extension assay (CEA) ${ }^{24}$ and methyl-acceptance assay (MAA), ${ }^{25}$ depending upon the singlenucleotide extension reaction and the function of methyltransferase, respectively. These methods can only afford indirect information about the genomic methylation levels. Nowadays, genomic DNA methylation is usually analyzed by high-performance liquid chromatography (HPLC) ${ }^{26,27}$ or capillary electrophoresis (CE) ${ }^{28-30}$ Among the known methods for the detection of genomic DNA methylation, CE coupled laser-induced fluorescence (LIF) analysis provides the best sensitivity and requires much less DNA (less than a microgram). However, these CE methods require DNA digestion followed by chemical derivatization of the mononucleotides, which are time-consuming and laborious. ${ }^{30}$

Here we describe a fluorescence polarization combined CE immunoassay for rapid and sensitive detection of genomic DNA methylation. The method does not require any of the bisulfite conversion, PCR amplification, or enzyme digestion. This is achieved by taking advantage of high specificity of a monoclonal antibody against 5-methylcytosine, highly efficient separation of capillary electrophoresis (CE), and high sensitivity of laser-induced fluorescence polarization (LIFP). Genomic DNA extracted from culture cells after incubation with antibodies can be directly subjected to CE-LIFP analysis. CE-LIFP has been applied for

(18) Esteller, M. Nat. Rev. Genet. 2007, 8, 286-298.

(19) Herman, J. G.; Graff, J. R.; Myohanen, S.; Nelkin, B. D.; Baylin, S. B. Proc. Natl. Acad. Sci. U.S.A. 1996, 93, 9821-9826.

(20) Eads, C. A.; Danenberg, K. D.; Kawakami, K.; Saltz, L. B.; Blake, C.; Shibata, D.; Danenberg, P. D.; Laird, P. W. Nucleic Acids Res. 2000, 28, e32.

(21) Gonzalgo, M. L.; Jones, P. A. Nucleic Acids Res. 1997, 25, 2529-2531.

(22) Xiong, Z.; Laird, P. W. Nucleic Acids Res. 1997, 25, 2532-2534.

(23) Voss, K. O.; Roos, K. P.; Nonay, R. L.; Dovichi, N. J. Anal. Chem. 1998, 70, 3818-3823.

(24) Pogribny, I.; Yi, P.; James, S. J. Biochem. Biophys. Res. Commun. 1999, $262,624-628$.

(25) Balaghi, M.; Wagner, C. Biochem. Biophys. Res. Commun. 1993, 193, 11841190.

(26) Eick, D.; Fritz, H. J.; Doerfler, W. Anal. Biochem. 1983, 135, 165-171.

(27) Friso, S.; Choi, S. W.; Dolnikowski, G. G.; Selhub, J. Anal. Chem. 2002, 74, 4526-4531.

(28) Fraga, M. F.; Rodríguez, R.; Cañal, M. J. Electrophoresis 2000, 21, 29902994.

(29) Fraga, M. F.; Uriol, E.; Diego, L. B.; Berdasco, M.; Esteller, M.; Cañal, M. J.; Rodríguez, R. Electrophoresis 2002, 23, 1677-1681.

(30) Stach, D.; Schmitz, O. J.; Stilgenbauer, S.; Benner, A.; Döhner, H.; Wiessler, M.; Lyko, F. Nucleic Acids Res. 2003, 31, e2. the study of protein-protein and protein-DNA interactions and aptamer based affinity analysis, ${ }^{31,32}$ and recently we demonstrated its unique capability of detecting the large DNA conformation change such as DNA wrapping around protein in solution. ${ }^{33}$ Here online fluorescence polarization incorporated in the $\mathrm{CE}$ immunoassay not only affords the confirmation of the immuno-complex of methylated DNA but also allows for the accurate quantitation of the target immuno-complex from the comigrated fluorescent dye.

\section{EXPERIMENTAL SECTION}

Reagents. Mouse antimethylcytosine monoclonal antibody (subclass, $\operatorname{IgG}_{1}$ ) was purchased from Calbiochem (La Jolla, CA). Alexa Fluor 546 labeled goat antimouse $\operatorname{IgG}_{1}$ fragment Fab (secondary antibody) was obtained from Invitrogen (Carlsbad, CA). Bovine serum albumin (BSA), lambda DNA, and 5-aza2'-deoxycytidine (5-Aza-dC) were purchased from Sigma (St. Louis, MO). E. coli $\mathrm{CpG}$ methyltransferase M. Sss I and E. coli restriction endonuclease Bst UI were supplied by New England BioLabs (Ipswich, MA). 5-Methyldeoxycytidine (5-mdC) and deoxycytidine were purchased from TCI (Tokyo, Japan) and Sigma (St. Louis, MO), respectively. Reagents used for cell culturing were obtained from Hyclone (South Logan, Australia). Other biochemicals were purchased from Sigma (St. Louis, MO) and Fisher Scientific (Pittsburgh, PA).

Preparation and Identification of Methylated DNA. Lambda DNA $(5.0 \mu \mathrm{g})$ was methylated by $20 \mathrm{U}$ of $\mathrm{CpG}$ methyltransferase M. Sss I at $37^{\circ} \mathrm{C}$ for $4 \mathrm{~h}$ as described previously. ${ }^{30} \mathrm{In}$ order to examine the methylation of lambda DNA, lambda DNA and methylated lambda DNA ( $0.5 \mu \mathrm{g}$ each) were digested by 10 $\mathrm{U}$ of restriction endonuclease $B s t \mathrm{UI}$ at $37^{\circ} \mathrm{C}$ for $4 \mathrm{~h}$, respectively. Digestion products were subjected to gel electrophoresis analysis on $0.8 \%$ agarose gel at the voltage of $100 \mathrm{~V}$ for 50 min, using $1 \times$ TBE (90 mM Tris-base, $90 \mathrm{mM}$ boric acid, and $10 \mathrm{mM}$ EDTA, $\mathrm{pH} \mathrm{8.0)}$ as electrophoresis buffer.

The methylation yield was further examined by enzymatic digestion followed by HPLC analysis. Lambda DNA and methylated lambda DNA ( $8.5 \mu \mathrm{g})$ were digested with $1 \mathrm{U}$ of DNase I, 2 $\mathrm{U}$ of alkaline phosphatase, and $0.005 \mathrm{U}$ of snake venom phosphodiesterase at $37{ }^{\circ} \mathrm{C}$ for $24 \mathrm{~h}$, respectively. The digested nucleoside mixtures were separated by HPLC on a $4.6 \mathrm{~mm} \times 250$ $\mathrm{mm}$ MP C18 column (5 $\mu \mathrm{m}$ in particle size, Agela Technologies Inc., Newark, DE) and detected at $260 \mathrm{~nm}$ with a ultraviolet (UV) detector. The mobile phase consisted of $\mathrm{H}_{2} \mathrm{O}$ (solvent $\mathrm{A}$ ) and acetonitrile (solvent B). A gradient of $25 \mathrm{~min} 4 \% \mathrm{~B}, 20 \mathrm{~min}$ $4-100 \% \mathrm{~B}$ was used and the flow rate was $0.8 \mathrm{~mL} / \mathrm{min}$. Under such conditions, 5-mdC was well separated from the other nucleosides. The standard curve of 5-mdC was prepared under the same HPLC conditions.

Capillary Electrophoresis and Laser-Induced Fluorescence Polarization Analysis (CE-LIFP). CE-LIFP analysis was conducted on a laboratory-built CE-LIFP system as described

(31) Yang, P.; Whelan, R. J.; Jameson, E. E.; Kurzer, J. H.; Argetsinger, L. S.; Carter-Su, C.; Kabir, A.; Malik, A.; Kennedy, R. T. Anal. Chem. 2005, 77, 2482-2489.

(32) Song, M.; Zhang, Y.; Li, T.; Wang, Z.; Wang, H. J. Chromatogr., A 2009, 1216, 873-878.

(33) Wang, H. L.; Lu, M. L.; Tang, M. S.; van Houten, B.; Ross, J. B. A.; Weinfeld, M.; Le, X. C. Proc. Natl. Acad. Sci. U.S.A. 2009, 106, 12849-12854. 
previously. ${ }^{34,35}$ Fluorescent species were excited by using a helium-neon green laser (543.5 nm, $1 \mathrm{~mW}$, Melles Griot, Irvine, $\mathrm{CA})$. The emitted fluorescence was split into horizontally and vertically polarized light beams by a polarizing beam splitter (Melles Griot, Nepean, Canada) and was measured by two photomultiplier tubes (PMT, model R1477, Hamamatsu Photonics, Japan) at $575 \mathrm{~nm}$, respectively. The current signals output from the two PMTs were transformed to voltage signals using a currentto-voltage converter and handled by the HW-2000 chromatographic workstation (Qianpu Software Co., Shanghai, China). Uncoated fused-silica capillaries (Yongnian Optic Fiber Plant, Hebei, China) were used with a total length of $27 \mathrm{~cm}$, effective length of $20 \mathrm{~cm}$, and a dimension of $25 \mu \mathrm{m}$ i.d. $\times 150 \mu \mathrm{m} \mathrm{o.d}$. unless otherwise stated. Samples were electrokinetically injected into the capillary by applying a voltage of $15 \mathrm{kV}$ for $5 \mathrm{~s}$ and separated by a voltage of $20 \mathrm{kV}$ at room temperature. Samples were prepared with the buffer of $2 \times$ TGA (14 mM Tris, $108 \mathrm{mM}$ Glycine, HAc $10.5 \mathrm{mM}, \mathrm{pH} 7.5$ ), and $\mathrm{CE}$ separation was conducted using the running buffer of $1 \times$ TG, pH $8.5(30 \mathrm{mM}$ Tris and $160 \mathrm{mM}$ glycine). This set of sample and separation buffers may allow for the focusing of the protein-DNA complexes as described previously ${ }^{36}$ and was adopted for effective focusing of the immuno-complex of methylated DNA. The capillary was electrophoretically reconditioned with $0.02 \mathrm{M} \mathrm{NaOH}$ followed by water and running buffer for 5 min each.

The fluorescence polarization (FP) values were calculated from the obtained intensity of the horizontally polarized fluorescence $\left(I_{\mathrm{h}}\right)$ and vertically polarized fluorescence $\left(I_{\mathrm{V}}\right)$ according to the following equation: ${ }^{37,38}$

$$
P=\frac{\left(I_{\mathrm{v}}-I_{\mathrm{h}}\right)}{\left(I_{\mathrm{v}}+I_{\mathrm{h}}\right)}
$$

Method Development Using Methylated lambda DNA. Methylated lambda DNA was denatured by heating at $95{ }^{\circ} \mathrm{C}$ for $5 \mathrm{~min}$, followed by chilling on ice for $10 \mathrm{~min}$ to prevent from reannealing, and then mixed with the primary and secondary antibody. The primary antibody (mouse antimethylcytosine monoclonal antibody) and the secondary antibody (Alexa Fluor 546 labeled $\mathrm{F}_{\mathrm{ab}}$ fragment of goat antimouse $\mathrm{IgG}_{1}$ ) were kept at the concentrations of 1.0 and $2.0 \mu \mathrm{g} / \mathrm{mL}$, respectively. Each sample with a total volume of $20 \mu \mathrm{L}$ was vortexed gently and incubated at $4{ }^{\circ} \mathrm{C}$ overnight, followed by CE-LIFP analysis.

To investigate the method sensitivity and dynamic range, a series of methylated lambda DNA (0, 0.1, 0.5, 1.0, 2.0, 5.0, 10, and $25 \mu \mathrm{g} / \mathrm{mL}$ ) were incubated with the two antibodies at $4{ }^{\circ} \mathrm{C}$, followed by CE-LIFP analysis. Unmethylated lambda DNA (0, 1.0, 5.0, 10, and $25 \mu \mathrm{g} / \mathrm{mL}$ ) was used for the CE-LIFP immunoassay to test the analytical specificity.

Methylated lambda DNA and unmethylated lambda DNA were mixed to make a solution containing $0 \%, 25 \%, 50 \%, 75 \%$, or $100 \%$ methylated DNA while the total DNA concentration was kept at $1.0 \mu \mathrm{g} / \mathrm{mL}$ for the CE-LIFP immunoassay.

(34) Wang, H. L.; Xing, J.; Tan, W.; Lam, M.; Carnelley, T.; Weinfeld, M.; Le, X. C. Anal. Chem. 2002, 74, 3714-3719.

(35) Wang, Z. X.; Wang, C.; Yin, J. F.; Li, T.; Song, M. Y.; Lu, M. L.; Wang, H. L. Electrophoresis 2008, 29, 4454-4462.

(36) Wang, H.; Lu, M.; Le, X. C. Anal. Chem. 2005, 77, 4985-4990.

(37) Wan, Q. H.; Le, X. C. Anal. Chem. 1999, 71, 4183-4189.

(38) Wan, Q. H.; Le, X. C. Anal. Chem. 2000, 72, 5583-5589.
Cell Culture and DNA Extraction. Human lung adenocarcinoma cell line A549 and hepatocellular carcinoma cell line HepG2 $\left(5 \times 10^{5}\right.$ cells) were seeded in culture medium for $24 \mathrm{~h}$ and then treated with $0.01,0.1,1.0,5.0$, and $10 \mu \mathrm{M}$ of 5 -AzadC. Cells were cultured in RPMI 1640 medium containing 10\% fetal calf serum, $100 \mathrm{U} / \mathrm{mL}$ penicillin, and $100 \mu \mathrm{g} / \mathrm{mL}$ streptomycin in $5 \% \mathrm{CO}_{2}$ at $37{ }^{\circ} \mathrm{C}$. The control cells were cultured in the same way but without the treatment of 5-Aza-dC. The cultured cells were harvested after $72 \mathrm{~h}$ treatment. Genomic DNA was extracted from harvested cells using a Genomic DNA Purification Kit (Promega, Madison, WI), according to the manufacture's instruction. DNA concentration and quality were estimated by measuring the absorbance at 260 and $280 \mathrm{~nm}$.

Genomic DNA Methylation Analysis. Genomic DNA methylation levels in extracted genomic DNA from treated or control culture cells were analyzed by the optimized method of the CE-LIFP immunoassay as described above for the detection of methylated lambda DNA. Genomic DNA extracted from culture cells was denatured by heating at $95{ }^{\circ} \mathrm{C}$ for $5 \mathrm{~min}$, followed by chilling on ice for $10 \mathrm{~min}$, and then mixed with the primary antibody $(1.0 \mu \mathrm{g} / \mathrm{mL})$ and the secondary antibody $(2.0 \mu \mathrm{g} / \mathrm{mL})$. Samples were vortexed gently and incubated at $4{ }^{\circ} \mathrm{C}$ overnight with a total volume of $20 \mu \mathrm{L}$, followed by CE-LIFP analysis. A series of genomic DNA from A549 cells with different concentrations $(0,1.0,5.0,10,25$, and $50 \mu \mathrm{g} / \mathrm{mL})$ was used for immunoreaction and CE-LIFP assay. The genomic DNA methylation level of A549 and HepG2 cells treated with 5-Aza-dC was also examined using this method.

\section{RESULTS AND DISCUSSION}

Detection of DNA Methylation by CE-LIF. To calibrate the genomic DNA methylation levels, methylated lambda DNA was first prepared as a standard. Lambda DNA (48502bp, $3112 \mathrm{CpG}$ sites) was treated for in vitro methylation of the cytosines in the CpG dinucleotides by $20 \mathrm{U}$ of $\mathrm{CpG}$ methyltransferase M. Sss I for $4 \mathrm{~h}$ at $37^{\circ} \mathrm{C}$. Bst UI restriction endonuclease was used to confirm the methylation. The restriction endonuclease Bst U I can recognize and cut the sequence of CGCG. There are about 157 CGCG sites in one lambda DNA molecule. If the cytosines in these sites are methylated, the methylated lambda DNA cannot be digested into fragments by Bst UI. After digested by Bst UI, unmethylated lambda DNA was separated into more than 10 fragments with different length by gel electrophoresis on $0.8 \%$ agarose (Figure 1, lane 2). In this case, there is no intact lambda DNA observable (Figure 1, lane 2). However, only one band was observed due to the intact DNA after the treatment of the methylated lambda DNA by Bst UI digestion (Figure 1, lane 4). The observation of only the intact lambda DNA indicates that the digestible restriction sites of Bst UI (CGCG) are completely destroyed by their cytosine methylation. It is not known whether the other $\mathrm{CpG}$ dinucleotide sites are methylated. However, the results confirm the effective methylation of lambda DNA by the CpG methyltransferase M. Sss I. To accurately quantify the methylation levels, the methylation yield of cytosine was further examined by using HPLC-UV analysis. The estimated 5-mdC in the methylated lambda DNA is about 1 in 20 nucleotides, or 150 $\mathrm{nM} 5$-mdC in $1.0 \mu \mathrm{g} / \mathrm{mL}$ DNA. There is no detectable 5 -mdC in the unmethylated lambda DNA (data not shown). 


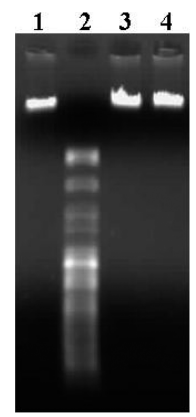

Figure 1. Gel electrophoresis analysis of $E$. coli restriction endonuclease Bst UI digested lambda DNA on $0.8 \%$ agarose. Lane 1 , lambda DNA; lane 2, lambda DNA digested with Bst UI; lane 3, methylated lambda DNA; and lane 4, methylated lambda DNA digested with Bst UI.

By the use of methylated lambda DNA, we further examined the possibility of capillary electrophoresis immunoassay for the detection of DNA methylation. The mouse antimethylcytosine monoclonal $\operatorname{IgG}_{1}$ antibody was used as a primary antibody $\left(1^{\circ}\right.$ $\mathrm{Ab})$ for specific recognition of methylated DNA. Alexa Fluor 546 labeled goat antimouse $\mathrm{IgG}_{1}$ fragment Fab was used as a secondary antibody $\left(2^{\circ} \mathrm{Ab}\right)$ for indirect labeling of the $1^{\circ} \mathrm{Ab}$ through noncovalently binding to the $\mathrm{Fc}$ region of the $1^{\circ} \mathrm{Ab}$. By CE-LIF analysis of the mixture of the two antibodies $\left(2^{\circ}\right.$ and $1^{\circ} \mathrm{Ab}$ ), two peaks show up (trace 1 , Figure 2 ). The $2^{\circ} \mathrm{Ab}$ cannot be separated from its complex with the $1^{\circ} \mathrm{Ab}$ and overlapped as one peak ( $0.8 \mathrm{~min}$, peak 1$)$. An additional peak (0.9 min, peak 2) appeared mainly due to the dissociated Alexa Fluor 546 dye from the fluorescently labeled $2^{\circ} \mathrm{Ab}$, which could be partially removed by a desalting treatment due to its small molecular size. The dissociation of the labeled fluorescent dye from the $2^{\circ} \mathrm{Ab}$ may be caused by the hydrolysis resulting from the instability of the covalent bond formed between the reactive group of the dye and the free amine of the secondary antibody.

By CE-LIF analysis of the mixtures of the two antibodies and the methylated lambda DNA, it was found that a significant amount of the immuno-complex of the methylated DNA $\left(2^{\circ} \mathrm{Ab}-\right.$ $1^{\circ} \mathrm{Ab}-\mathrm{DNA}$, peak 2 ) could be observed only for ssDNA but not for dsDNA (traces 2 and 3, Figure 2). However, the immunocomplex of the methylated ssDNA was overlapped with the dissociated fluorescent dye and appeared together in the peak 2 (trace 3, Figure 2). The single strand of the methylated lambda DNA was obtained by denaturing the methylated dsDNA at 95 ${ }^{\circ} \mathrm{C}$ for $5 \mathrm{~min}$, followed by chilling on ice. The results indicate that the mouse antimethylcytosine monoclonal antibody prefers to react with the methylated DNA in the form of a single strand. Therefore, in followed CE immunoassay, the dsDNA was denatured into single stranded DNA before incubating with the two antibodies.

Quantitation of Immuno-Complex of Methylated DNA from Unresolved Fluorescent Dye by Online Fluorescence Polarization. Since the dissociated dye comigrates with the immuno-complex of the methylated DNA $\left(2^{\circ} \mathrm{Ab}-1^{\circ} \mathrm{Ab}-\mathrm{mDNA}\right)$ during $\mathrm{CE}$ separation, we propose to exploit the online coupled laser-induced fluorescence polarization to deprive the immunocomplex of methylated DNA from the dissociated fluorescent dye without further separation. Fluorescence polarization is an important analytical measurement which reflects the rotational diffusion of the fluorescent tag at the nanosecond scale. ${ }^{39,40}$ In general, small dye molecules rapidly rotate and exhibit negligible fluorescence polarization. When bound to the macromolecules (e.g., proteins and DNA), the tagged dye molecules will rotate slower and gain significantly increased polarization. From the view of our experimental measurement of the fluorescence polarization, the fluorescence that is induced by vertically excited laser beam can be split into two types of fluorescence, namely, horizontally polarized light $\left(I_{\mathrm{h}}\right)$ and vertically polarized lights $\left(I_{\mathrm{v}}\right)$ (Supporting Information, Figure S1). The untagged dye with negligible polarization has an equal fluorescence response of horizontally polarized light and vertically polarized light. By taking advantage of this feature, it is possible to eliminate the interference from the overlapped fluorescent dye by the subtraction of $I_{\mathrm{v}}-I_{\mathrm{h}}$. In this case, since $I_{\mathrm{v}}=I_{\mathrm{h}}, I_{\mathrm{v}}-I_{\mathrm{h}}$ should be equal to zero, leading to the computational removal of the dissociated fluorescence dye. The tagged dye with non-negligible polarization has a larger response in vertically polarized light than that in horizontally polarized light $\left(I_{\mathrm{v}}>I_{\mathrm{h}}\right)$ when covalently bonded to the $2^{\circ} \mathrm{Ab}$. Therefore, the fluorescence from the dye tagged on the large $2^{\circ} \mathrm{Ab}$ and its immuno-complex $\left(2^{\circ} \mathrm{Ab}-1^{\circ} \mathrm{Ab}-\mathrm{mDNA}\right)$ can be partially kept after subtraction $\left(I_{\mathrm{v}}-I_{\mathrm{h}}>0\right)$. As shown in Figure 3a, two electropherograms (traces 1 and 2) obtained from the CE-LIFP analysis of the DNA-absent mixture of the two antibodies $\left(2^{\circ} \mathrm{Ab}\right.$ and $\left.1^{\circ} \mathrm{Ab}\right)$ correspond to the horizontal and vertically polarized fluorescence signals $\left(I_{\mathrm{h}}\right.$ and $\left.I_{\mathrm{v}}\right)$. By subtraction $\left(I_{\mathrm{v}}-I_{\mathrm{h}}\right)$, another electropherogram (trace 3 ) was obtained. By careful examination of peak 2 in traces 1 and 2 in Figure $3 \mathrm{a}$, it was observed that peak 2 consisted of two parts ( $a$ and $b$ ), in which $b$ was a shoulder of peak 2 . As shown in the insert of the Figure $3 \mathrm{a}$, the peak $2 \mathrm{a}$ shows $8 \%$ left and the peak $2 \mathrm{~b}$ almost disappears after subtraction. The partial remainder of the peak 2a suggests that peak $2 \mathrm{a}$ is probably due to the unknown protein-dye conjugate that has a nonzero polarization and cause incomplete subtraction. The disappearance of peak $2 \mathrm{~b}$ suggests that peak $2 \mathrm{~b}$ is due to the dissociated dye. The results also prove that the dissociated dye with negligible polarization can be effectively eliminated.

The CE-LIFP analysis of the mixture of the two antibodies and the methylated DNA $(3 \mu \mathrm{g} / \mathrm{mL})$ showed that there were also two split peaks in peak 2 (peaks $2 \mathrm{a}$ and $2 \mathrm{~b}$, Figure $3 \mathrm{~b}$ ). However, both split peaks (peaks $2 \mathrm{a}$ and $2 \mathrm{~b}$ ) remain after subtraction (Figure $3 \mathrm{~b})$. It is interesting that the separation of the two split peaks (peaks $2 \mathrm{a}$ and $2 \mathrm{~b}$ ) shows better separation resolution (at least 2 times) after subtraction than that without subtraction.

The method sensitivity was estimated by detecting the immuno-complex of the methylated DNA formed by the two antibodies and the methylated lambda DNA of $0.01 \mu \mathrm{g} / \mathrm{mL}$ (Figure $3 c$ ). By calculation from the ratio of signal-to-noise (peak $2 b$ ), the limit of detection (LOD, $\mathrm{S} / \mathrm{N}=3$ ) was estimated about $0.002 \mu \mathrm{g}$ / $\mathrm{mL}(\sim 0.3 \mathrm{nM}$ methylcytosine).

Specificity of the CE-LIFP Immunoassay. To investigate the specificity of the CE-LIFP immunoassay, we tested the formation of the immuno-complex of DNA-antibody in the presence of the methylated lambda DNA and the unmethylated lambda DNA, respectively. The concentrations of lambda DNA

(39) Le, X. C.; Wan, Q. H.; Lam, M. T. Electrophoresis 2002, 23, 903-908. (40) Li, T.; Wang, H. L. Anal. Chem. 2009, 81, 1988-1995. 


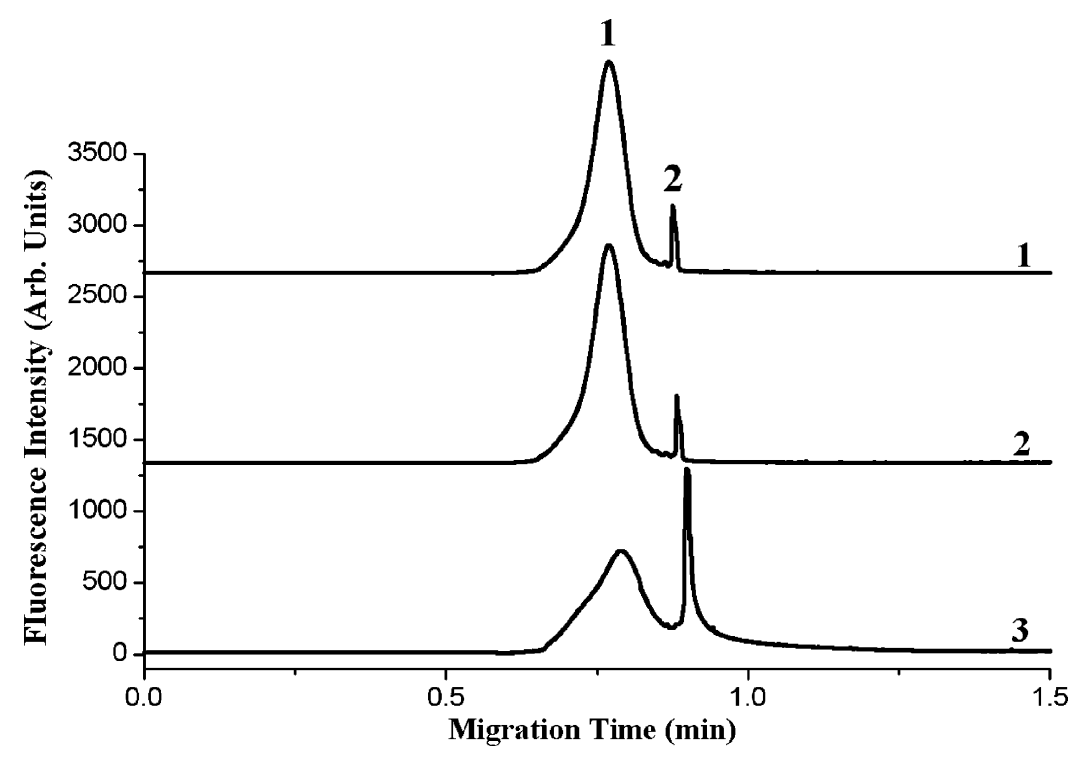

Figure 2. CE-LIF immunoassay of the methylated lambda DNA, showing the formation of the immuno-complex from single stranded DNA but not from double stranded DNA. The methylated lambda DNA is $3.0 \mu \mathrm{g} / \mathrm{mL}$. The fluorescence was excited at $543 \mathrm{~nm}$ and detected at $575 \mathrm{~nm}$. Traces 1, 2, and 3 were correspondingly obtained from the CE-LIF analysis of the mixture of $1^{\circ} \mathrm{Ab}$ and $2^{\circ} \mathrm{Ab}$, the mixture of $1^{\circ} \mathrm{Ab}, 2^{\circ} \mathrm{Ab}$, and the methylated lambda DNA in a double strand, and the mixture of $1^{\circ} \mathrm{Ab}, 2^{\circ} \mathrm{Ab}$, and the methylated lambda DNA in a single strand. For the detailed CE-LIF immunoassay conditions, see the Experimental Section.

and the methylated DNA were varied from 0.1 to $25 \mu \mathrm{g} / \mathrm{mL}$. It is evident for the methylated DNA that the signal of the immunocomplex increases with the increasing concentration of the methylated lambda DNA (Figure 4A). The immuno-complex can be detectable even for the methylated lambda DNA with the concentration as low as $0.1 \mu \mathrm{g} / \mathrm{mL}$. In such case, only was $1.0 \mathrm{pg}$ methylated lambda DNA injected for one CE-LIFP analysis. When the concentration of the methylated lambda DNA is over $10 \mu \mathrm{g} /$ $\mathrm{mL}$, the amount of the formed immunocomplex of methylated DNA-antibody nearly approaches to a plateau, indicating the state of binding saturation of the primary antibody (Figure 4a). The unmethylated lambda DNA was also tested in parallel as a negative control. Even in the presence of $25 \mu \mathrm{g} / \mathrm{mL}$ of unmethylated lambda DNA, there is no significant immuno-complex of DNAantibody observed (Figure 4a). The results clearly indicate that the developed method is specifically applied for the detection of DNA methylation, and the cross-reaction over the unmethylated DNA by the antimethylcytosine antibody is negligible.

To further examine the specificity of the CE-LIFP immunoassay, the methylated lambda DNA was mixed with the unmethylated lambda DNA in a varied ratio while the total concentration of DNA was kept at $1.0 \mu \mathrm{g} / \mathrm{mL}$. The occupied percentage of the methylated lambda DNA is over $0 \%, 25 \%, 50 \%, 75 \%$, and $100 \%$. It was observed that an excellent linear relationship with a correlation coefficient of $R^{2}=0.99$ was shown between the peak area of the immuno-complex of DNA and the percentage of methylated DNA (Figure 4b). The results confirmed no cross-reaction of the antimethylcytosine antibody against the unmethylated DNA. The CE-LIFP immunoassay also shows excellent reproducibility. The relative standard deviation for each sample is below $5.0 \%$ $(n=3$ or 4$)$.

Genomic DNA Methylation Analysis. We demonstrate the method development of the CE-LIFP immunoassay for rapid and sensitive detection of DNA methylation using methylated lambda DNA as an example. We further examined whether the developed method could be applied to the detection of the methylation level of genomic DNA using genomic DNA extracted from cultured human cell lines as an example. In this experiment, we first determined the methylation level of genomic DNA from human A549 cells (Supporting Information, Figure S2A). It is clear that the genomic DNA extracted from human A549 cells can form a significant amount of immuno-complex of DNA (peak 2, Supporting Information, Figure S2A), indicating the methylation of genomic DNA in human A549 cells. The electropherogram of the CE-LIFP immunoassay for the detection of the methylation of the genomic DNA is similar to that obtained from the detection of methylated lambda DNA. The formed immuno-complex of DNA is proportional to the involved concentration of the genomic DNA $(0-50 \mu \mathrm{g} / \mathrm{mL}$ ) (Supporting Information, Figure S2B), showing an excellent linearity $\left(R^{2}=0.99\right)$. Therefore, the results prove that our method is applicable for the detection of genomic methylation from cultured cells. In this test, it was found that the use of genomic DNA of $1.0 \mu \mathrm{g} / \mathrm{mL}$ for the CE-LIFP immunoassay could give reliable values on the levels of genomic DNA methylation. The relative standard deviation is below $5.0 \%(n=3)$. In such a case, the injected volume is about $10 \mathrm{~nL}$, and it was estimated that about $10 \mathrm{pg}$ of DNA had been injected into the capillary for one CE-LIFP analysis. By simplification, one human tissue cell contains one molecule of $3.3 \times 10^{9}$ bp DNA, which equals $3.4 \mathrm{pg}$ of DNA. The injected amount of $10 \mathrm{pg}$ of DNA is comparable to that of 3 human cells, indicating the potential of the application of the method for the detection of genomic DNA methylation in several human cells. In practical applications, it requires more cells for a microliter volume based incubation reaction. However, it is possible to realize the detection of genomic DNA methylation in several cells if combining the single cell capillary electrophoresis technology. ${ }^{41}$

At last, we demonstrate the detection of genomic DNA hypomethylation caused by the treatment of chemicals. In this

(41) Turner, E.; Cohen, D.; Pugsley, H.; Gómez, D. G.; Whitmore, C.; Zhu, C.; Dovichi, N. J. Anal. Bioanal. Chem. 2008, 390, 223-226. 
(a)

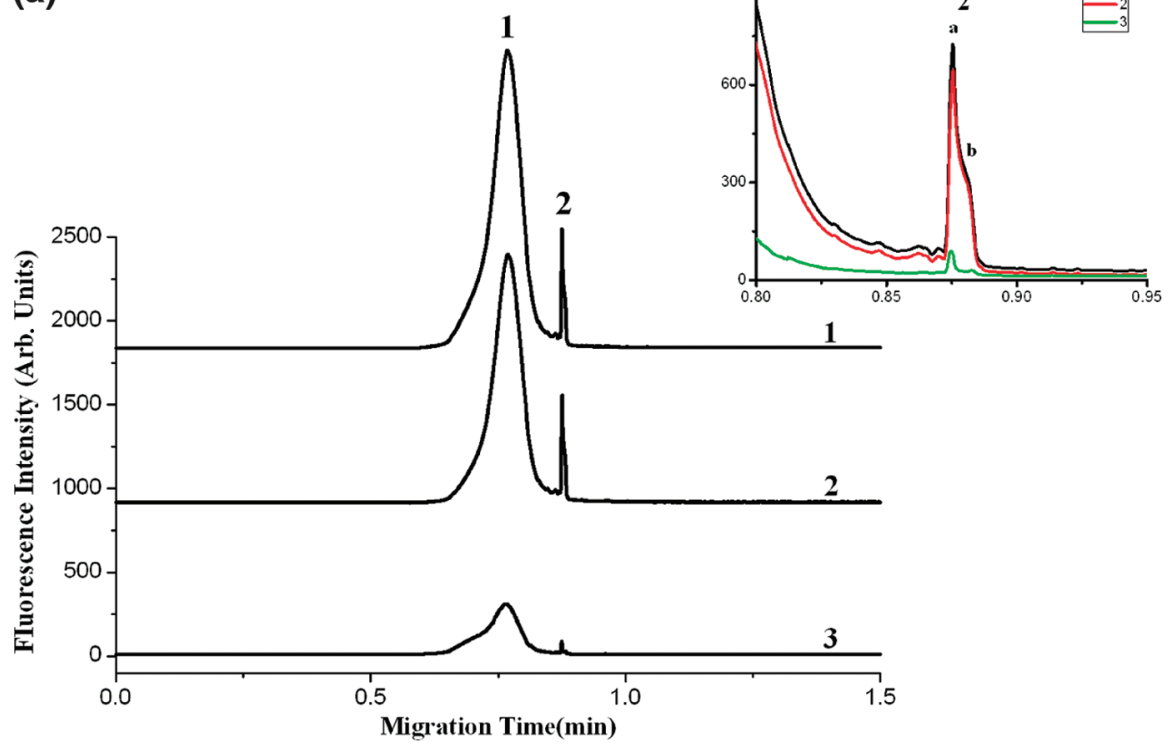

(b)

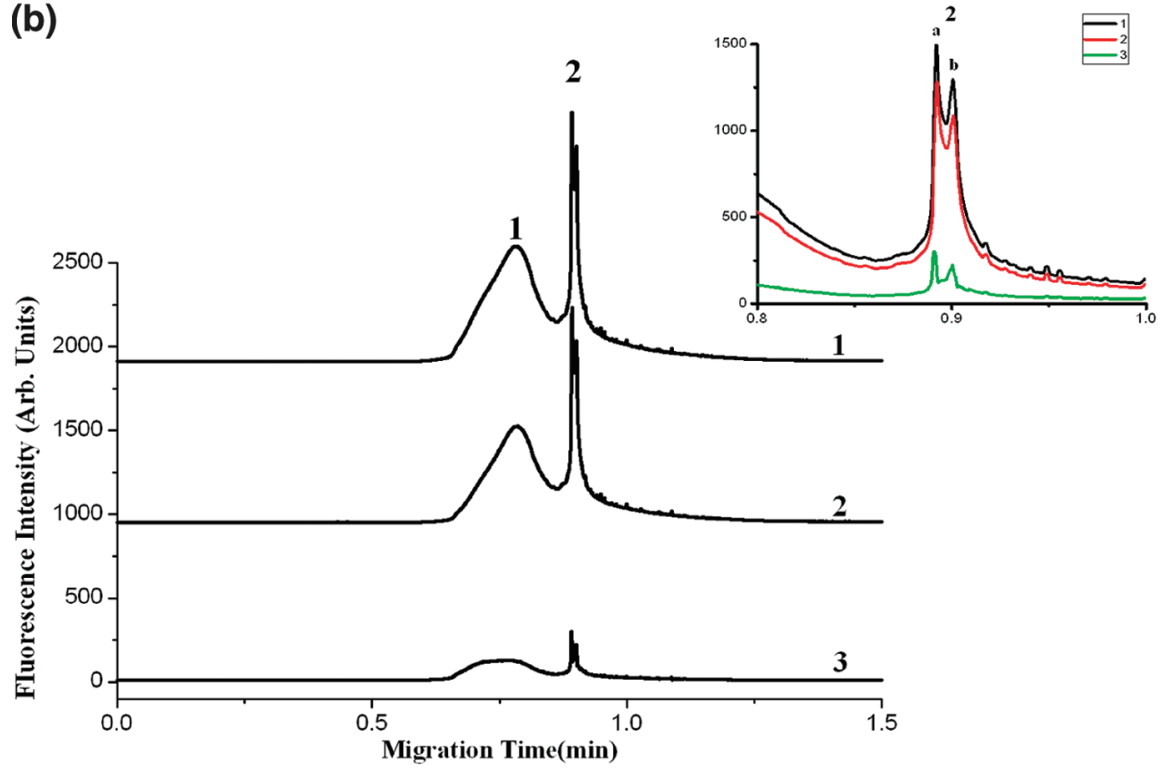

(c)

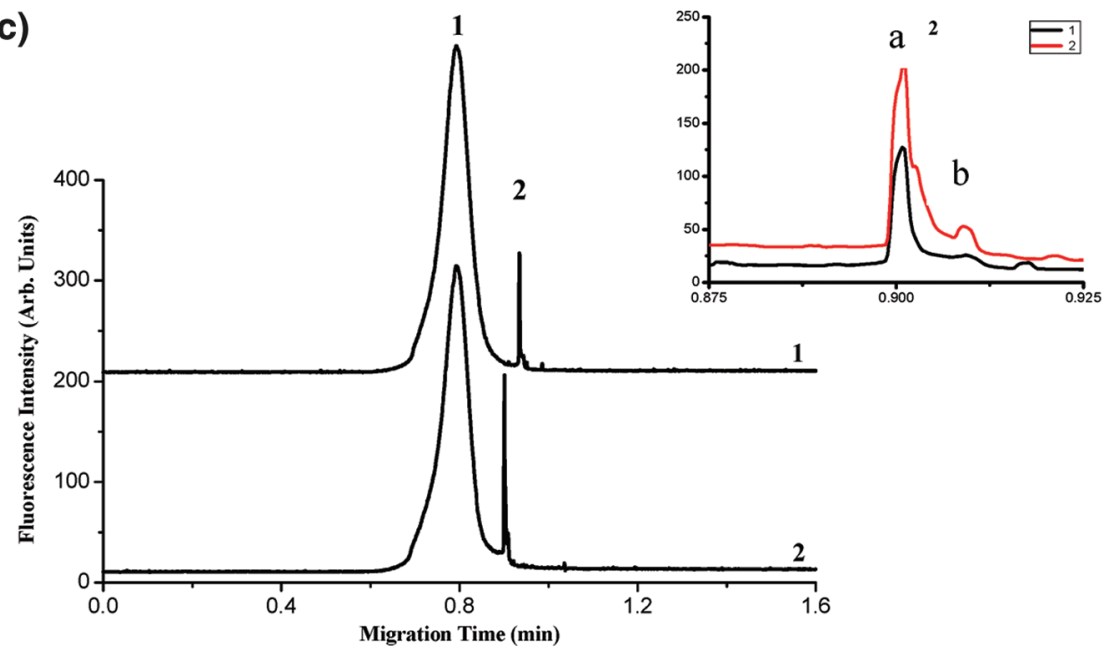

Figure 3. Quantitation of the immuno-complex of the methylated DNA from the comigrated fluorescent dye by fluorescence polarization subtraction. (a) CE-LIFP analysis of the mixture of the two antibodies $\left(1^{\circ} \mathrm{Ab}\right.$ and $\left.2^{\circ} \mathrm{Ab}\right)$ only. Traces $1-3$ are the corresponding signals from $I_{\mathrm{h}}, I_{v}$, and $I_{v}-I_{\mathrm{h}}$. (b) CE-LIFP analysis of the mixture of the two antibodies and $3.0 \mu \mathrm{g} / \mathrm{mL}$ methylated lambda DNA. Traces $1-3$ are the signals as indicated in part a. (c) The subtracted electropherograms obtained from CE-LIFP immunoassays in the presence of $0.01 \mu \mathrm{g} / \mathrm{mL}$ methylated lambda DNA (trace 2) and the absence of DNA (trace 1). 


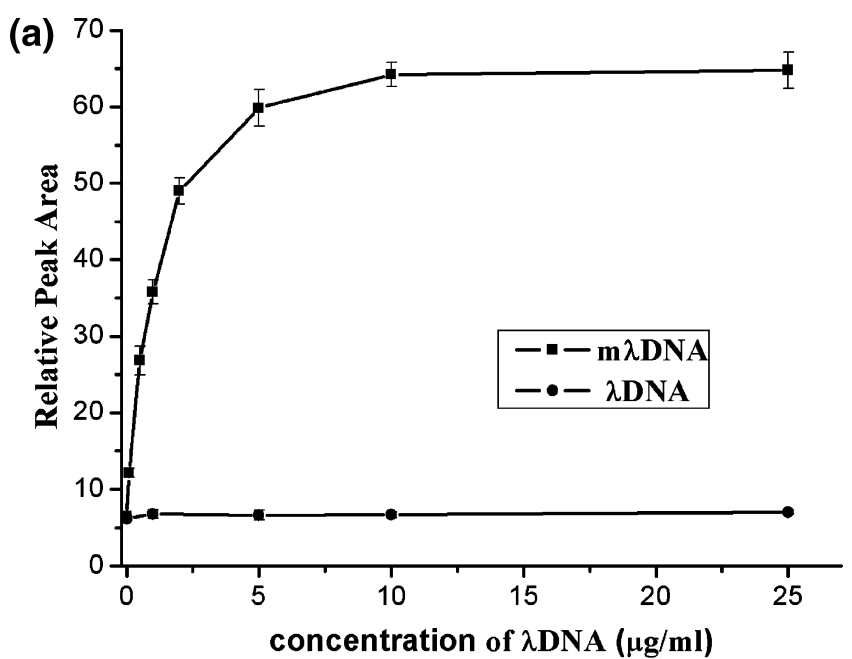

(b)

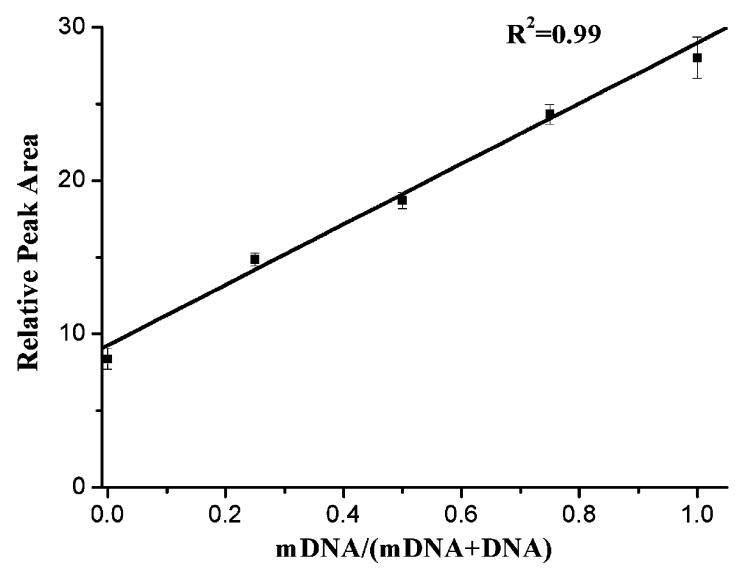

Figure 4. The methylation of the lambda DNA dependent formation of an immuno-complex of DNA, showing the high specificity of the CE-LIFP immunoassay of DNA methylation. (a) The change in the relative peak area of the formed immuno-complex of DNA vs the concentration of methylated lambda DNA $(\mathbf{\square}, 0-25 \mu \mathrm{g} / \mathrm{mL})$ or unmethylated lambda DNA $(\bullet, 0-25 \mu \mathrm{g} / \mathrm{mL})$. (b) The linear relationship between the relative peak area of the immuno-complex and the percentage of methylated lambda DNA in the total lambda DNA. The total concentration of DNA was kept at $1.0 \mu \mathrm{g} / \mathrm{mL}$. The relative peak area was estimated by dividing the peak area of the immuno-complex of DNA by the peak area of the DNA unbound $2^{\circ} \mathrm{Ab}(n=3)$.

experiment, 5-Aza-dC, a representative inhibitor of DNA methyltransferase, ${ }^{42}$ was used as an example. A549 and HepG2 cells were separately treated for $72 \mathrm{~h}$ before being harvested by 5 -Aza-dC $(0,0.01,0.1,1,5$, and $10 \mu \mathrm{M})$. Then, genomic DNA was extracted, was incubated with the two antibodies, and was subjected to the CE-LIFP immunoassay. In both A549 and HepG2 cells, the methylation level of genomic DNA decreases with the increasing concentration of 5-Aza-dC (Figure 5), showing significant dosedependent inhibition of the methylation of genomic DNA by 5-AzadC. The inhibition of genomic DNA methylation (about 10-20\%) can be observed in the two cell lines even treated with trace 5-Aza$\mathrm{dC}$ as low as $0.01 \mu \mathrm{M}$. Genomic DNA methylation level in A549 cells is down-regulated over $64 \%$ after being treated with $10 \mu \mathrm{M}$ 5-Aza-dC for 72 h. As with HepG2 cells, the reduction is about $46 \%$. These results confirm that our method is applicable for the rapid detection of genomic DNA methylation.

(42) Dunn, B. K. Ann. N.Y. Acad. Sci. 2003, 983, 28-42.

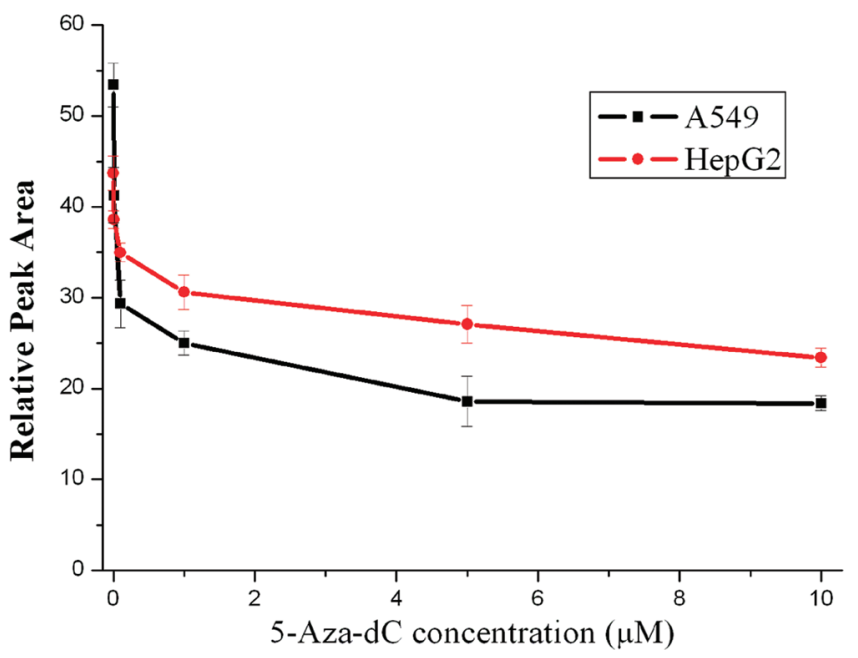

Figure 5. The dose-dependent inhibition of the genomic DNA methylation by the typical methyltransferase inhibitor 5-Aza-dC in A549 and HepG2 cells.

In summary, we describe a new method for the detection of the genomic DNA methylation level by using antimethylcytosine monoclonal antibody coupled with CE-LIFP. The advantages of CE-LIFP immunoassay for the detection of genomic DNA methylation includes no need for bisulfite conversion, PCR amplification, or enzymatic digestion of DNA, less than $1 \mathrm{ng}$ of genomic DNA required, and high speed (1.2 min for CE-LIFP analysis). In addition, it is possible to provide high-throughput analysis in combination with 96 array capillary electrophoresis. With the online laser-induced fluorescence polarization detection, the target immuno-complex can be distinguished and quantitatively measured from the comigrated dye without further separation. We also demonstrate the application of the developed method for rapid and sensitive detection of the DNA methylation change in genomic DNA from chemically treated cells. Since aberrant DNA methylation has been detected in a wide range of cancers and can be used as a biomarker of cancer cells, the developed method can be used for cancer risk assessment through human biomonitoring of the genomic DNA methylation level. Many environmental exposures that may associate with a number of human diseases are supposed to exert toxicological effects at the epigenetic levels. With its high sensitivity and high speed, our method can be also useful for the analysis of the genomic DNA methylation change related to environmental exposures.

\section{ACKNOWLEDGMENT}

This work was supported by the Grants from the National Basic Program of China (973 Program, 2007CB407305, 2008CB417201, and 09CB421605), the National Natural Science Foundation of China (20877091, 20737003, and 20621703), and the Chinese Academy of Sciences (YZ200749) to Dr. H. Wang.

\section{SUPPORTING INFORMATION AVAILABLE}

Additional information as noted in text. This material is available free of charge via the Internet at http://pubs.acs.org.

Received for review July 28, 2009. Accepted August 31, 2009.

\section{AC901681K}

